FEDERAL RESERVE BANK OF SAN FRANCISCO

WORKING PAPER SERIES

\title{
Are There Productivity Spillovers from Foreign Direct Investment in China?
}

\author{
Galina Hale \\ Federal Reserve Bank of San Francisco \\ Cheryl Long \\ Colgate University
}

February 2007

http://www.frbsf.org/publications/economics/papers/2006/wp06-13bk.pdf

The views in this paper are solely the responsibility of the author and should not be interpreted as reflecting the views of the Federal Reserve Bank of San Francisco or the Board of Governors of the Federal Reserve System. This paper was produced under the auspices of the Center for Pacific Basin Studies within the Economic Research Department of the Federal Reserve Bank of San Francisco. 


\title{
Are there Productivity Spillovers from Foreign Direct Investment in China?
}

\author{
Galina Hale* \\ Federal Reserve Bank of San Francisco
}

Cheryl Long ${ }^{\dagger}$

Colgate University

FEBRUARY 2007

\begin{abstract}
We review previous literature on productivity spillovers of foreign direct investment (FDI) in China and conduct our own analysis using a firm-level data set from a World Bank survey. We find that the evidence of FDI spillovers on the productivity of Chinese domestic firms is mixed, with many positive results largely due to aggregation bias or failure to control for endogeneity of FDI. Attempting over 2500 specifications which take into account forward and backward linkages, we fail to find evidence of systematic positive productivity spillovers from FDI.
\end{abstract}

JEL classification: L33, F23, O17

Keywords: FDI, spillovers, forward-backward linkages, China

*galina.b.hale@sf.frb.org. Hale is grateful to the Stanford Center for International Development for financial support and hospitality during work on this project.

${ }^{\dagger}$ cxlong@mail.colgate.edu. Long thanks the Hoover Institution for financial support and hospitality during work on this project.

We thank Robert Deckle, Bob Hall, Oscar Jorda, Ted Moran, Bob Turner, Bin Xu, Kent Zhao and the participants of the ASSA session on "Understanding the Mechanisms of China's Economic Growth" for invaluable suggestions and Chris Candelaria for outstanding research assistance. We are grateful to Runtian Jing for sharing the data. All errors are ours. The views in this paper are solely the responsibility of the authors and should not be interpreted as reflecting the views of the Federal Reserve Bank of San Francisco. 


\section{Introduction}

China has been extremely successful in attracting foreign direct investment (FDI) since it started the economic reforms at the end of the 1970s. Figure 1 illustrates the breathtaking speed of FDI growth in China. Annual FDI inflow was below $\$ 100$ million in 1979 , but exceeded $\$ 580$ billion in 2006 , with an annual growth rate of close to $30 \%$. Such rapid growth of FDI inflow has largely been accompanied by government policies that encourage FDI, as described in detail in Hale and Long (2006). Some of these policies aimed to equalize operating conditions for foreign capital inside and outside China, including those regarding foreign trade and foreign exchange control. Other policies provided monetary incentives for foreign investors, including preferential treatment in taxation and environmental regulation. While policies that level the playing grounds for foreign firms operating outside and inside China are prerequisites for capital inflow that seeks higher rate of returns, the policies that subsidize foreign investors through lower tax rates and lenient environmental requirements can only be justified if positive externalities on domestic firms are created with the inflow of FDI (Moran, 2007).

Although FDI growth and the effectiveness of government policies in prompting such growth have been unrefuted, the effects of FDI on domestic firms are far from clear. Previous studies on FDI spillover effects on productivity of Chinese firms have produced mixed evidence as to whether domestic firms have benefited from FDI presence. Due to limited availability of the firm-level panel data and difficulty in finding instruments for FDI presence, many positive results obtained by researches suffer from an upward bias due to aggregation or endogeneity of FDI.

In this paper we discuss these and other potential biases that arise in existing literature on FDI spillovers in China. We also conduct our own analysis using a data set from a World Bank stratified survey of firms in five cities and ten industries. While our data set lacks time dimension, it contains very rich information on many aspects of firms' state and behavior. In addition to limiting the sample to domestic firms, which removes the aggregation bias, we apply instrumental variables analysis to address potential endogeneity of FDI presence, using three variables that do not affect domestic firms' productivity directly. We also control for non-random selection that arises when limiting the sample to domestic firms and could bias estimates downward. After controlling for these biases, we fail to find any significant FDI spillover effects on TFP or labor productivity for domestic firms in the same, upstream or downstream industries.

We believe that there are institutional factors that may explain the lack of productivity spillovers of FDI in China. For instance, one important channel of spillovers is technology transfer through labor mobility. In China, however, labor mobility across regions and industries is still limited due to formal labor market 
Figure 1: FDI inflows into China

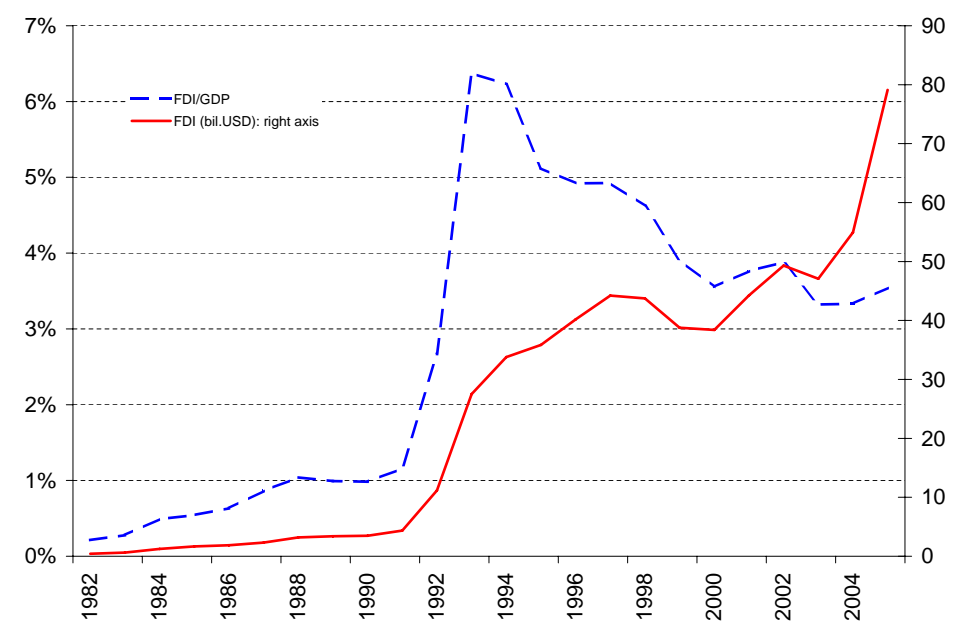

Source: CEIC China Database, Global Financial Data

restrictions and informal barriers. In addition, because of still limited competitive pressure on businesses in many industries, the incentives to adopt superior technology for domestic firms may be weak, lowering potential productivity spillovers from FDI presence $\left.\right|^{1}$ Furthermore, limited access to credit by private firms is likely to be limiting their ability to adopt new technologies.

The current paper relates closely to the literature on FDI spillovers as well as that on transition economies, which we review in the next section. It also contributes to the literature in several aspects. First, we carefully address the endogeneity of FDI presence by instrumenting it with exogenous variables such as location, transportation conditions, and tax rates. Second, we include service sector firms in addition to manufacturing firms. Third, we use the input-output table for China to study the vertical spillover effects of FDI, i.e., spillover effects of FDI in upstream and downstream industries in addition to spillovers to the firms in the same industry, or horizontal spillovers. Fourth, we explore the effects of ownership structure on FDI spillover effects on domestic firms.

The structure of the paper is as follows: Section 2 reviews previous literature on productivity spillovers of FDI in China and identifies potential biases in the estimates. Section 3 describes the data and empirical approach used in the study. Empirical results are presented in Section 4. Section 5 concludes.

\footnotetext{
${ }^{1}$ These points were raised in a recent paper by Moran (2007).
} 


\section{Review of empirical literature}

Theoretical work has generally predicted positive effects of FDI presence on domestic firms' productivity through the labor mobility channel (Kaufmann, 1997; Haaker, 1999; Fosfuri, Motta, and Rønde, 2001; Glass and Saggi, 2002) or through competition and demostration effects (Wang and Blomstrom, 1992). These models predict same-industry, or horizontal, spillovers. In addition, Rodriguez-Clare (1996) outlines forward and backward linkages between foreign firms and domestic firms as a possible mechanism for positive spillovers.

However, the results from empirical studies are mixed. Most studies focus on the spillover effects of FDI on domestic firms in the same industry. For example, among the 42 studies on horizontal productivity spillovers of FDI in developed, developing, and transition economies summarized in Görg and Greenaway (2004), only 20 studies report unambiguously positive and significant results. Furthermore, 14 out of the 20 studies finding positive effects either use cross-section data at the industry level, which leads to aggregation bias we discuss below, or use cross-section of firm level data without controlling for the endogeneity of FDI presence. Among the 24 studies using firm level panel data, which Görg and Greenaway (2004) argue to be the most appropriate estimating framework, only 5 obtain positive and significant FDI spillover effects, with 4 from developed countries. For transition economies, only one out of the 8 studies discussed obtains positive and significant FDI spillover effects, using cross-section data.

The results appear more conclusive for vertical spillovers. Among the five studies discussed in Görg and Greenaway (2004) that focus on vertical FDI spillover effects, i.e., effects of FDI presence on domestic firms located in upstream or downstream firms, three find positive backward FDI spillovers, one finds positive forward FDI spillovers. In addition Javorcik (2004) and Blalock and Gertler (2007) find positive vertical FDI spillovers in Latvia and Indonesia, respectively.

Similar to findings for other countries, studies on FDI spillover effects in China have obtained a wide range of estimates for the effects of FDI presence on the productivity of Chinese domestic firms. We summarize published studies of FDI spillover effects on productivity of Chinese firms in Table 1. As shown in Column (2), most studies of FDI spillover effects in China focus on how the presence of FDI affects the total factor productivity (TFP) of domestic firms, their labor productivity or both, with the exception of Cheung and Lin (2004), which studies patent applications, and Buckley, Clegg, and Wang (2002), which include high-tech and new product development as well as export performance in addition to labor productivity. 


\subsection{Potential biases in empirical literature}

Before discussing the results of the empirical studies on FDI spillovers in China, we would like to address the biases that may arise when estimating the effect of foreign presence on the productivity of domestic firms. To fix ideas, suppose that there are $I$ industries indexed $i=\{1, \ldots I\} \bigsqcup^{2}$ each containing $N_{i}$ firms. Suppose $M_{i}<N_{i}$ of these firms are domestic and the rest are foreign-invested (which we will call foreign, for short). The most common measure of FDI presence in industry $i$ is then

$$
F D I_{i}=\frac{\sum_{j=M_{i+1}}^{N_{i}} w_{j}}{\sum_{j=1}^{N_{i}} w_{j}}
$$

where $w_{j}$ is some weight (usually employment or sales), indicating the size of each firm. Thus, $F D I_{i}$ is size--weighed share of foreign firms in industry $i:^{3}$

To simplify the discussion, and without loss of generality, assume that all firms have the same size, and therefore

$$
F D I_{i}=\frac{N_{i}-M_{i}}{N_{i}}
$$

The most common way to estimate the FDI spillover effect is by fitting the regression

$$
y_{j i}=\alpha+\beta F D I_{i}+\gamma l_{j i}+\delta k_{j i}+\varepsilon_{j i}
$$

where $y_{j i}=\log Y_{j i}$ is $\log$ of value added by firm $j$ from industry $i, l_{j i}=\log L_{j i}$ is $\log$ of employment, $k_{j i}=\log K_{j i}$ is $\log$ of capital. This approach assumes the production function of the form $Y_{j i}=A_{j i} L_{j i}^{\gamma} K_{j i}^{\delta}$, where $\log A_{j i}=\alpha+\beta F D I_{i}+\varepsilon_{j i}=a_{i}+\varepsilon_{j i}$ is a log of total factor productivity of firm $j$ from industry $i$, which has an industry-specific component $a_{i}$ that is tested for being linked to the presence of FDI in the industry. Thus, $\alpha$ is a common component, or mean TFP, $\beta$ measures the extent of spillovers from FDI presence, while $\varepsilon_{j i}$ is a mean-zero firm-specific error term assumed to be orthogonal to $F D I_{i}{ }^{4}$ The hypothesis being tested is $\mathrm{H} 0: \beta>0$.

\section{Aggregation bias}

\footnotetext{
${ }^{2}$ These can also be interpreted as cities, provinces, industry-province or industry-city cells.

${ }^{3}$ Alternatively, the numerator can be $\sum_{j=1}^{N_{i}} w_{j} s_{j}$, where $s_{j}$ is the share of foreign ownership in firm $j$, or the share of ownership by the largest foreign partner, the measure we adopt in our own regressions, below.

${ }^{4} \mathrm{~A}$ common alternative is to estimate $y_{j i}-l_{j i}=\alpha+\delta F D I_{i}+\delta\left(k_{j i}-l_{j i}\right)+\varepsilon_{j i}$, which assumes, in addition, constant returns to scale.
} 
Suppose that the firm-level data is not available, as it is commonly the case, and therefore estimation is conducted at the aggregated level, $i$-level, for instance, by province or industry. An important assumption in the FDI spillover literature is that foreign-invested firms have better technology that spills over to domestic firms through various channels. Thus, it is assumed that foreign-invested firms are more productive than firms without foreign partners $5^{5}$ In the studies that use aggregate data, foreign firms are frequently not excluded from the aggregates, thus, using our notation, the following equation is estimated,

$$
\bar{y}_{i}=\alpha+\beta F D I_{i}+\gamma \bar{l}_{i}+\delta \bar{k}_{i}+\varepsilon_{i}
$$

where $\bar{y}_{i}=1 / N_{i} \sum_{j=1}^{N_{i}} y_{j i}, \bar{l}_{i}=1 / N_{i} \sum_{j=1}^{N_{i}} l_{j i}, \bar{k}_{i}=1 / N_{i} \sum_{j=1}^{N_{i}} k_{j i}$.

Suppose all the firms are identical in all respects, except that all foreign firms' TFP is higher by a constant. Denoting domestic firms with superscript $d$ and foreign firms with superscript $f, Y_{i}^{d}=A_{i}^{d} L_{i}^{\gamma} K_{i}^{\delta}, Y_{i}^{f}=$ $A_{i}^{f} L_{i}^{\gamma} K_{i}^{\delta}$, with $A_{i}^{f}>A_{i}^{d}, \forall i$. This also implies that $a_{i}^{f}=\log A_{i}^{f}>a_{i}^{d}=\log A_{i}^{d}$. Then, by construction, the higher is the share of foreign firms, the higher is the aggregated measure of TFP:

$$
a_{i}=\frac{M_{i}}{N_{i}} a_{i}^{d}+\frac{N_{i}-M_{i}}{N_{i}} a_{i}^{f}=\left(1-F D I_{i}\right) a_{i}^{d}+F D I_{i} a_{i}^{f}=a_{i}^{d}+F D I_{i}\left(a_{i}^{f}-a_{i}^{d}\right)
$$

so that $\partial a_{i} / \partial F D I_{i}>0$ whenever $a_{i}^{f}>a_{i}^{d}$. Thus, when estimating Equation (2) at the aggregated level across $i$ with $a_{i}=\alpha+\beta F D I_{i}$, one automatically finds $\beta>0$, even if individual domestic firms' TFP is not affected by the presence of FDI. In other words, the estimates of spillover effects obtained from aggregate regressions are subject to an upward aggregation bias that can be avoided by excluding foreign firms from the aggregates or using firm-level data.

\section{Selection bias}

Unfortunately, estimating the model on the subset of domestic firms, or using the aggregates that exclude foreign-ivestment firms is not without flaws either. The first problem arises due to the very likely possibility of non-random selection.

Suppose relevant FDI are mergers and acquisitions (M\&A) rather than greenfield investment. Further suppose that foreign firms choose to invest in domestic firms that are more productive ex ante (the cherrypicking phenomenon we already referred to), as opposed to investing at random and making firms more

\footnotetext{
${ }^{5}$ Because of the "cherry-picking" phenomenon, when foreign investor choose to invest in the first that are a priori more productive, it is notoriously difficult to show empirically the productivity effects of foreign ownership. In a notable exception, Arnold and Javorcik (2005) show, for the case of Indonesia, that foreign-invested firms perform better than similar domestic firms.
} 
productive ex post. We can rank all domestic firms in industry $i$ before the FDI according to their TFP, so that $A_{1 i}<A_{2 i}<\ldots A_{N i}, \forall i \in[1, I]$. For simplicity, suppose that distribution of $A_{j i}$ is the same for all industries and that the distribution of industry-level foreign investment across industries is orthogonal to the distribution of $A_{j i}$.

Cherry-picking implies that foreign capital flows to the firms in the upper tail of $A_{j i}$ distribution. Thus, the TFP distribution of the firms that remain domestic after FDI inflow is upper-truncated. Moreover, the truncation point $M_{i}$ is lower the higher is the share of FDI firms in the industry. Thus, $a_{i}=1 / M_{i} \sum_{j=1}^{M_{i}} a_{j i}$ is lower the lower is the share of domestic firms (i.e. the higher is the share of FDI), and $\partial a_{i} / \partial F D I_{i}<0$. As a result, when Equation (1) is estimated for domestic firms only, with $a_{i}=\alpha+\beta F D I_{i}$, one automatically finds $\beta<0$, in the absence of actual FDI spillovers. In other words, firm-level cross-section regressions that are limited to domestic firms yield estimates of productivity spillovers of FDI that are biased downward if cherry-picking is present. It is easy to see that the same is true for aggregate analysis that excludes foreign firms from the aggregates.

The problem of selection bias can be addressed by estimating a model of sample selection, which allows for the selection of the firms into domestic and foreign categories to be correlated with firms' productivity. Of course, this approach would require firm-level data, including the data on foreign invested firms. More specifically, a Heckman (1979) selection model can be employed, using, for example, a maximum likelihood estimation of two simultaneous equations

$$
\left\{\begin{array}{cl}
\operatorname{Prob}\left(D O M_{j i}\right) & =\lambda_{0}+Z_{j i}^{\prime} \Lambda+\nu_{j i} \\
y_{j i} & =\alpha+\beta F D I_{i}+\gamma l_{j i}+\delta k_{j i}+\varepsilon_{j i}, \text { if } D O M_{j i}=1
\end{array}\right.
$$

where $D O M_{j i}$ is an indicator for whether firm $j$ is classified as domestic, and $Z_{j i}$ is a matrix of firm-level and aggregate characteristics that include $l_{j i}, k_{j i}$ as well as instruments that may explain the probability of foreign investment into a given firm but are orthogonal to firms' TFP ${ }^{6}$

\section{Endogeneity of FDI}

While the problem of non-random selection discussed above is relatively easy to resolve 7 there remains another source of bias in the cross-section firm-level analysis, potential endogeneity of FDI. Suppose TFP varies across industries for reasons unobserved by an econometrician and that the FDI flow into industries

\footnotetext{
${ }^{6}$ Because the functional form of the selection equation is well specified, it can be used for identification even without instruments. However, identification in this case tends to be weak and sensitive to specification errors.

${ }^{7}$ In fact, selection bias turns out not to be very important quantitatively in our data set.
} 
that are a priori more productive, i.e., $a_{i}$ varies across $i$ and $F D I_{i}=f\left(a_{i}\right), f^{\prime}>0$. Then, when estimating Equation (1), one finds $a_{i}=\alpha+\beta F D I_{i}=\alpha+\beta f\left(a_{i}\right)$, and therefore $\beta=\frac{1}{f^{\prime}\left(a_{i}\right)}>0$. Thus, one will find that $\beta>0$ even in the absence of positive productivity spillovers from FDI. Thus, endogeneity of FDI would lead to an upward bias in the estimates of the productivity spillover of FDI.

The best way to address this problem is to estimate a fixed-effects, or difference-in differences, model with individual firm fixed effects, using the panel of domestic firms. Note that the panel would have to include a large enough time span because FDI does not vary much over time ${ }^{8}$

Alternatively, an instrumental variables approach could be used by instrumenting $F D I_{i}$ with variables uncorrelated with $a_{i}$. Specifically, one can estimate, using 2SLS or GMM, the following system:

$$
\left\{\begin{aligned}
F D I_{i} & =\mu+{\overline{Z^{\prime}}}_{i} \Upsilon+\omega_{i} \\
y_{j i} & =\alpha+\beta F D I_{i}+\gamma l_{j i}+\delta k_{j i}+\varepsilon_{j i}
\end{aligned}\right.
$$

where $\bar{Z}_{i}$ is a matrix that includes industry-level instruments for $F D I_{i}$, which are uncorrelated with $a_{i}$, as well as firm characteristics, averaged for industry $i$.

\section{Downward bias in standard errors}

Finally, since the measure of FDI presence is, by necessity, an aggregate measure, one should take care of the potential correlation of the standard errors in the firm-level regressions (Moulton, 1990). In particular, in Equation (1), disturbances $\varepsilon_{j i}$ will not be i.i.d., but rather will be correlated within each $i$. If the standard errors are calculated based on the assumption of i.i.d. disturbances, they will be biased downward, mistakenly leading to a conclusion that the estimates are statistically significant even if they are not. This problem can be easily remedied by computing robust standard errors clustered on industry $i$.

\subsection{Empirical literature on productivity spillovers of FDI in China}

When the four potential problem outlined above are taken into consideration, we will argue that although many of the studies included in Table 1 find positive and significant FDI spillovers, most of these studies tend to overestimate FDI spillover effects on Chinese domestic firms, with Hu and Jefferson (2002) being the only exception. Depending on the level of data aggregation, studies on FDI spillovers in China can be divided into provincial level studies, industry level studies, and firm level studies. First, as we showed

\footnotetext{
${ }^{8}$ In our data, lacking time dimension, we use city and industry fixed effects which absorb some of this bias.
} 
above, studies using provincial or industry level data often do not exclude firms with foreign investment from the sample (Huang, 2004; Cheung and Lin, 2004; Liu, Parker, Vaidya, and Wei, 2001), and are, therefore, subject to an upward aggregation bias. Second, most studies do not control for the endogeneity of FDI when estimating its spillover effects. Therefore, the positive correlation between FDI and productivity of domestic firms may simply reflect the location decision by foreign investors rather than the positive spillover effects of their investment 9

As shown in Table 1 provincial level studies are not able to distinguish domestic firms from foreign invested firms. Thus, both of the papers listed in the top panel of the table (Huang, 2004; Cheung and Lin, 2004) suffer from an upward aggregation bias 10 Three out of four studies using industry level data, summarized in the second panel of Table 1, do separate domestic firms from foreign invested firms, and two out of the three such studies, Li, Liu, and Parker (2001) (LLP2001) and Buckley, Clegg, and Wang (2002) (BCW2002) find positive FDI spillover effects. Both studies explore the manufacturing sector using the 1995 Third Industrial Census of China. While Li, Liu, and Parker (2001) only explore the FDI effects on labor productivity, Buckley, Clegg, and Wang (2002) also study the potential FDI spillovers on other measures of firm performance (including high-tech and new product development as well as export performance) and finds positive spillover effects. However, neither study addresses the endogeneity of FDI. Buckley, Clegg, and Wang (2002) use ordinary least squares, while Li, Liu, and Parker (2001) uses three-stage least squares to address the endogeneity of value added of firms with different ownership types. Thus, both of these studies potentially suffer from an upward bias due to endogeneity of FDI.

The third study (Liu, 2001) only find positive significant spillovers when using overall average FDI measure. However, as we discussed above, the standard errors are likely to be underestimated in this case. Finally, Liu, Parker, Vaidya, and Wei (2001) (LLPW2001) do not exclude foreign firms and therefore their estimates are subject to an upward aggregation bias, as well as the bias due to endogeneity.

We are aware of only three published studies that use firm level data, listed in the bottom panel of Table 1, and among the three only two make use of the variation at the firm level. In the third, Chuang and Hsu (2004) (CH2004) begins with 455689 firms from the 1995 Third Industrial Census of China but aggregate the firm level data to 673 industry-province cells. Using OLS estimation, they find positive and significant FDI spillover effects on domestic firms that have low technology gap from foreign firms. In addition to the potential bias due to the endogeneity of FDI, the definition of technology gap (defined as the difference of average sales revenue per worker between foreign-invested firms and domestic firms) is also potentially

\footnotetext{
${ }^{9}$ In fact, studies that analyze the location of FDI in China, including Sun, Tong, and Yu (2002) and Cheng and Kwanb (2000), tend to find a positive correlation between per capita GDP (positively related to productivity) and FDI.

${ }^{10}$ These papers are referred to as Huang2004 and CL2004, respectively.
} 
endogenous. Thus, the positive FDI effects obtained are likely to be biased.

Similarly, in an unpublished paper, Tong and Hu (2003) aggregate close to 500,000 domestic firms to 10601 4-digit industry-province cells and find that FDI from the Greater China Area (GCA, including HongKong, Macao, and Taiwan) have negative effects on domestic productivity while that from other areas have positive effects. They also study inter-industry spillovers by estimating the effects on the 4-digit industry-province cell's productivity of the average FDI share in the corresponding 2-digit industry-province cell. For FDI from both the GCA and other areas, the authors obtain positive and significant inter-industry spillover effects. Once again, because the paper does not control for the endogeneity of FDI either by using firm fixed effects or by instrumenting, these results are likely to be subject to an upward bias ${ }^{11}$

Wei and Liu (2006) (WL2006) use a panel data from the Annual Report of Industrial Enterprise Statistics, including close to 8000 Chinese domestic firms for 1998-2001. This provides an ideal setting for addressing the issue of endogenous FDI by estimating a model with firm fixed effects. However, Wei and Liu (2006) only controls for year, industry, and area fixed effects, but not firm fixed effects possibly due to insufficient variance of FDI over time in their short panel. As a result, there is an upward bias in the FDI spillover effects estimated if the industry, the province, or the industry-province cell that have more productive domestic firms also tend to attract more foreign investment. Another potential upward bias may come from the sample exclusion criterion used in the paper, where any firm with less than $25 \%$ of foreign equity participation is defined as a domestic firm, making it more likely to find higher productivity in industries with more FDI, if foreign investment makes firms more productive.

$\mathrm{Hu}$ and Jefferson (2002) (HJ2002) is the only study we are aware of that includes estimates not subject to the endogeneity problem. The study uses 8917 domestic textile firms and 2289 domestic electronic firms and find negative and significant effects of FDI presence on the TFP of domestic electronic firms. But the more convincing findings are from the authors' panel data analysis of 701 textile firms and 212 electronic firms for 1995-1999, which includes firm fixed effects. If the unobserved factors that determine both the amount of FDI and the productivity of domestic firms are time invariant, then estimates of FDI spillovers in Hu and Jefferson (2002) do not suffer from the upward biases outlined above. The results from the FE estimation show negative but insignificant FDI spillover effects.

In summary, empirical evidence of FDI spillovers on Chinese domestic firms is mixed, largely because data limitation has hampered the effort to control for the endogenous location of FDI. Thus, while many of the reviewed studies find positive spillover effects of FDI, the estimates are likely to be biased upward. In fact,

\footnotetext{
${ }^{11}$ We are not aware of the studies that analyze specifically vertical spillovers of FDI in the case of China. While one might argue that the endogeneity of FDI is less of a problem in such inter-industry studies, it is still possible that foreign firms choose to invest in the industries which enjoy forward and backward linkages with (already) more productive firms.
} 
the study that addresses the endogeneity problem, does not find positive effects. The message we take from the literature is, therefore, that the evidence of FDI spillovers on domestic firms' productivity in China is inconclusive.

\section{$3 \quad$ Data and empirical approach}

In the rest of the paper, we describe our own analysis that addressed the concerns raised above. In addition to the potential biases, previous research suffers from limited coverage of industry and narrow scope of spillover measures. With the exception of Huang (2004) and Cheung and Lin (2004), which look at the total FDI amount at the provincial level, all other studies focus on the manufacturing sector in China. In terms of the scope of spillovers, all studies use TFP and labor productivity, except Cheung and Lin (2004) and Buckley, Clegg, and Wang (2002). In addition, all previous studies (except Tong and Hu (2003)) focus on the spillover effects of FDI in the same location or industry, while ignoring potential FDI spillovers through backward and forward linkages, shown to be important for other transition economies (Javorcik, 2004).

In the following sections, we present results from our own analysis using a firm-level data set from a World Bank survey. We attempt to address the limitations of previous studies as follows: First, we limit our sample to firms without any foreign partners; Second, while we do not have a time dimension that would allow us to use firm fixed effects, we address the endogeneity of FDI by instrumenting for the level of FDI; Third, we control for potential selection bias; Fourth, we study both manufacturing firms and service firms. Finally, we explore potential spillover effects of FDI presence in upstream and downstream industries. We now describe the data and outline our empirical approach.

\subsection{Data}

We use data from the Study of Competitiveness, Technology \& Firm Linkages conducted by the World Bank in 2001, eight years after the surge of FDI to China. While the data lacks time dimension, it is abundant in information at the firm level.

The survey consists of two questionnaires, one filled up by the Senior Manager of the main production facility of the firm while the other filled up by the accountant or personnel manager of the firm. The methodology of the survey is stratified random sampling with the stratification based on sub-sectors including accounting and related services, advertising and marketing, apparel and leather goods, business logistics services, communication services, consumer products, electronic equipment and components, IT, and auto parts. A stratified random sample of 300 establishments is drawn in each of the following five Chinese cities: 
Beijing, Chengdu, Guangzhou, Shanghai, and Tianjin, giving a total sample size of 1500 . Table 2 gives the city and industry distribution of firms included in the survey. Throughout the paper, we refer to firms with a foreign partner as 'foreign' or 'foreign-owned' firms and firms without a foreign partner as domestic firms. As shown in Table 2 , among the 1500 firms interviewed during the survey, 382 are foreign firms in 2000.

The survey collects detailed information on firms and their operation environment. The firms were requested to provide information as of year 2000, but for many accounting measures, information from up to three previous years was also collected 12

In addition to the comprehensive scope of information collected and the high response rate, our survey data has another advantage. A main concern to researchers studying FDI in China, round-tripping FDI is domestic capital disguised as FDI by registering firms at offshore financial centers that have lax controls on capital movements, which then invest in China. In our sample, however, only three out of the 381 firms with foreign partners list the British Virgin Islands as the FDI source country and only one lists the Cayman Islands, two of the most used offshore financial centers in round tripping FDI. Excluding these four firms from our sample does not substantially change the results. In other words, our data seems to suffer less from the bias associated with round-tripping FDI ${ }^{13}$

In this study, we use a small portion of the survey that gives information on firms' input, output, as well as foreign ownership. In particular, we use the following variables directly or constructed from the survey, with all values referring to year 2000 unless indicated otherwise:

Value added: Firm sales (adjusted by change in final product inventory) minus total material costs, in year 2000 RMB, used in logs.

Capital input: Value of fixed assets in year $2000 \mathrm{RMB}$, used in logs.

Labor input: Number of employees in the firm, used in logs.

TFP: Total factor productivity obtained as a residual from linear regression of value added on capital and labor input for each industry on the sample of domestic firms.

Y/L: Labor productivity equal to the ratio of value added to labor input, used in logs.

Capital/Labor: Capital intensity of the firm, measured as the ratio between capital input and labor input. Firm age: Firm's age.

Firm scale: Firm sales relative to the average firm sales in the same industry, used in logs.

Degree of competition: Number of competitors the firm has relative to the average number of competitors in the same industry, used in logs.

\footnotetext{
${ }^{12}$ For a detailed description of the survey, see Hallward-Driemeier, Wallsten, and Xu (2003).

${ }^{13}$ Another main location used for round tripping FDI is Hong Kong. We address this concern by using a measure of non-GCA FDI presence, where GCA (or the Greater China Area) includes Hong Kong, Macao, and Taiwan.
} 
CEO-college: An indicator of whether the CEO of the firm has a college degree.

CEO-grad. degree: An indicator of whether the CEO of the firm has a post-graduate degree.

Favorable regulations: An indicator of whether favorable regulatory environment is among the top five reasons given for choosing the current location of the firm.

Average education: Average education level of engineering and managerial personnel in the firm, in years of schooling.

Average age: Average age of engineering and managerial personnel in the firm, in years.

Tax rate: The amount of taxes paid divided by sales.

Exporter: An indicator for whether the firm is exporting some of its products.

Transportation cost: Transportation expenses divided by sales.

Industry: Industry sector of the firm, a categorical variable $1,2, \ldots, 10$.

City: City where the firm is located, a categorical variable $1,2, \ldots, 5$.

Largest foreign partner: The share of the largest foreign partner in firm's ownership.

Foreign ownership share: Total share of foreign ownership, including portfolio investment.

Country of largest foreign partner: The country where the headquarters of the largest foreign partner are located.

EPZ: An indicator for whether the firm is located in National Export Procession Zone (EPZ).

Table 3 shows summary statistics for the variables used in the analysis. The sample of our analysis will include only domestic firms, but we provide the averages for these variables for foreign firms as well, for comparison. Domestic firms with private ownership of less than $20 \%$ are listed as SOEs, while others are listed as private ${ }^{14}$ Table 3 suggests that foreign firms are substantially different from domestic firms in age, scale, capital intensity, and labor productivity, especially compared to domestic SOEs.

The crucial variable in the study is the measure for FDI presence. Following the literature (Aitken and Harrison (1999), for instance), we define and construct the measure of FDI presence in the same industry as the average of each firm's largest foreign partner's share in the same city-industry as the domestic firm, weighted by firm employment 15 Table 4 presents this measure by city and industry sector. We use this measure of FDI presence when focusing on the horizontal FDI spillover effects, within the same geographic location and industry.

To allow for inter-industry FDI spillover effects, we construct an input-output table for industries included in our sample based on the 2000 Input-Output Table for China, as shown in Table $55^{16}$ Using this table,

\footnotetext{
${ }^{14}$ This split corresponds most closely to the ownership characterizations provided by the firms.

${ }^{15}$ In our test we also use the measure of FDi that takes into account total foreign ownership share and not only largest partner's share. We call it FDI+portfolio presence.

${ }^{16}$ The 2000 Input-output Table for China was accessed at http://www.stats.gov.cn/tjsj/ndsj/yb2004-c/html/C0322ac.htm on December 30, 2006.
} 
we compute the upstream FDI presence for firm $j$ as the sum of FDI presence in all other industries in the same city weighted by the input coefficients of these industries corresponding to firm $j$ 's industry. The downstream FDI presence, on the other hand, is computed as the sum of FDI presence in all other industries weighted by the output coefficients of firm $j$ 's industry to these other industries. Table 6 presents summary statistics for upstream and downstream FDI presence by city and industry sector.

We test additional hypotheses by constructing a variety of measures for FDI presence. Since the degree of connection with local firms may be influenced by whether a firm has majority foreign ownership, it is possible that the sign and magnitude of FDI spillover effects may vary depending on the presence of firms with majority foreign ownership ${ }^{17}$ To test this hypothesis, we construct the presence of FDI by focusing on majority ownership foreign firms and construct FDI-majority presence measure by including only the foreign shares of firms with majority foreign ownership in our computation of FDI presence.

The source region of foreign ownership may also be relevant in determining FDI spillover effects. Several studies find that foreign investment from the Greater China Area (GCA) tends to be less technology intensive compared to FDI from other countries and regions ${ }^{18}$ We therefore construct the presence of non-GCA FDI, by computing the average of each firm's largest non-GCA partner's share in the same city-industry as the domestic firm, weighted by firm employment.

Many of the foreign-invested firms in China's port cities use their factories primarily as export platforms. While they might be using more advanced technologies, their interaction with domestic firms is likely to be limited. In this case, it would make sense to focus on the firms that are more present in the domestic markets and actually compete with domestic firms. To do this, we compute the FDI presence as the average foreign share of firms weighted by the product of their domestic sales to total sales ratio and their employment. Moran (2007), on the other hand, argues that foreign invested firms that are more export oriented tend to have more positive spillovers on domestic firms, because they put competition pressure on domestic firms (specially domestic suppliers) to match quality and efficiency requirements by clients overseas.

In addition, many of the foreign-invested firms are located in the special economic zones that are designed for producing export products, EPZ. It can be argued that these firms are isolated from the rest of the firms in the city and are unlikely to contribute to the technological spillovers (Moran, 2007). To address this concern, we also construct a measure of FDI presence which excludes those firms located in EPZ's.

\footnotetext{
${ }^{17} \mathrm{Xu}$ and $\mathrm{Lu}(2006)$ finds that the impact of foreign firms' presence on the sophistication of Chinese exports differs depending whether the foreign invested firms have majority foreign ownership. Moran (2007) further argues that only wholly owned foreign firms are likely to transfer technology because the headquarters tend to withdraw advanced technology from joint ventures. However, in our sample, we do not find a significant difference in the instances of technology transfer from the headquarters between the wholly and partially foreign owned firms.

${ }^{18}$ See, for instance, Buckley, Clegg, and Wang (2002), Huang (2004), Hu and Jefferson (2002), Tong and Hu (2003), Wei and Liu (2006), and Xu and Lu (2006),.
} 
Having constructed these additional FDI measures, we then use the Input-Output Table to compute the corresponding upstream and downstream FDI presence. In our regression analysis we use the measures of FDI presence in levels as well as in logs. To summarize, we use the following measures of FDI presence:

FDI presence: The average of each firm's largest foreign partner's share in the same city-industry as the domestic firm, weighted by firm employment.

Upstream FDI presence: The sum of FDI presence (as defined above) in all other industries in the same city as the domestic firm, weighted by the input coefficients of these industries to the industry of the firm.

Downstream FDI presence: The sum of FDI presence (as defined above) in all other industries in the same city as the domestic firm, weighted by the output coefficients to these industries of the industry of the firm.

FDI+portfolio presence: The average of each firm's total foreign ownership share in the same cityindustry as the domestic firm, weighted by firm employment.

FDI-majority presence: The average of the largest foreign partner's share of the firms with majority foreign stake in the same city-industry as the domestic firm, weighted by firm employment.

FDI-non GCA presence: The average of each firm's largest foreign partner's share (excluding partners from GCA - Hong Kong, Taiwan, and Macao) in the same city-industry as the domestic firm, weighted by firm employment.

FDI-domestic sales presence: The average of each firm's largest foreign partner's share in the same cityindustry as the domestic firm, weighted by the product of the firm's domestic sales to total sales ration and firm's employment.

FDI-non EPZ presence: The average of each firm's largest foreign partner's share (excluding firms located EPZ) in the same city-industry as the domestic firm, weighted by firm employment.

For all of the above variables, we also construct corresponding measures of the upstream and downstream FDI presence.

We use the following variables from outside of our survey data to construct the instruments for FDI presence, as discussed below:

Port berth: The total number of berths (including both productive and non-productive ones) in the port located by the city (valued at 0 if the city has no port), obtained from Chinese Statistical Yearbook 2001, National Bureau of Statistics.

Distance between cities: The distance between the capital city of each province or autonomous region and the cities in our sample, obtained from the official web site of the China National Materials, Storage 
and Transportation Corporation $\sqrt{19}$

Provincial population: The population of each province or autonomous region, obtained from Chinese Statistical Yearbooks 2001, National Bureau of Statistics.

\subsection{Empirical approach}

Our focus is on the effects of foreign presence on performance of domestically owned firms. Thus, the sample of our main analysis is limited to domestic firms and is not subject to the aggregation bias that occurs when lumping together foreign and domestic firms. Our main regression specification is therefore:

$$
Y_{j i c}=\alpha_{i}+\alpha_{c}+\beta_{1} F D I_{i c}+Z_{j i c}^{\prime} \Gamma+\varepsilon_{j i c}
$$

where $Y_{j i c}$ is a performance measure for firm $j$ operating in industry $i$ and located in city $c, \alpha_{i}$ and $\alpha_{c}$ are industry and city fixed effects, respectively, $F D I_{i c}$ is a measure of foreign firm presence in the same cityindustry cell as firm $j, Z_{j i c}$ is a set of firm-level control variables corresponding to the outcome variable, $\varepsilon_{j i c}$ is a random error term. Thus, the coefficient $\beta_{1}$ measures the relationship between foreign presence in a city-industry cell and the characteristic of an average domestic firm measured by the outcome variable. When studying the backward and forward linkages of FDI effects, we use the upstream and downstream FDI presence as the FDI measure.

As discussed above, the biggest challenge in accurately estimating FDI spillover effects is potential endogeneity of FDI. To address this issue in our cross-section data, we adopt the instrumental variable (IV) approach. Blonigen (2005) argues that multinational corporations make overseas investment for several reasons, including obtaining lower tax rate, securing access to domestic market, and using cheap local resources, such as labor, to produce for other markets ${ }^{20}$ We therefore use the following three instruments for FDI, which are not correlated with productivity of domestic firms: the average tax rate of all firms in the cityindustry, obtained as simple average of the tax rate of the firms in each city-industry cell, the percentage of firms in the industry that exported in year 2000 multiplied by the berth capacity of the city's seaport (Port $*$ export), and the average transportation cost as a percentage of sales in the industry multiplied by the sum of population of all other provinces weighted by the inverse of the distance between the provincial

\footnotetext{
${ }^{19}$ http://www.cmst.com.cn/mileage/mileage.asp last accessed on January 29, 2007.

${ }^{20}$ Empirical studies demonstrating the importance of these factors include de Mooij and Ederveen (2003) (tax rate), Coughlin, Terza, and Arromdee (1991) (tax rate and infrastructure), Ma (2006) (access to international market), Bagchi-Sen and Wheeler (1989) (population size, population growth, and per capita sales), and Kravis and Lipsey (1982) and Blomstrom and Lipsey (1991) (size of domestic market). Razin, Rubinshtein, and Sadka (2005) shows the importance of tax rate in determining FDI flow both theoretically and empirically using EU data. Other studies on location of FDI in China include Cheng and Kwanb (2000) and Sun, Tong, and Yu (2002).
} 
capital and the city squared (Dist $*$ trcost).

The average tax rate in the city-industry proxies for preferential tax treatments some locations and sectors receive and thus affects the attractiveness of the city-industry to foreign investors. The capacity of the seaport affects the cost of exporting, while the percentage of firms that export serves as a proxy for the importance of exporting in a particular industry. Thus, Port $*$ export measures the access to overseas market and the attractiveness to FDI of the particular city-industry cell. The sum of population of all other provinces weighted by the square of the inverse of their distance to a city gives a measure of how centrally located the city is, while the average transportation cost as a percentage of sales measures the bulkiness of the industry. Dist $*$ trcost therefore measures the access to the domestic market and thus the attractiveness to FDI of the city-industry. Table 7 gives the means of the three instruments by city and industry ${ }^{21}$

Specifically, we estimate, using two-stage least squares (2SLS) and generalized method of moments (GMM), the following system:

$$
\left\{\begin{aligned}
F D I_{i c} & =\delta_{i}+\delta_{c}+\delta_{1} T A X_{i c}+\delta_{2} \text { Port } * \text { export }_{i c}+\delta_{3} \text { Dist } \text { trcost }_{i c}+{\overline{Z^{\prime}}}_{i c} \Phi+\omega_{i c} \\
Y_{j i c} & =\alpha_{i}+\alpha_{c}+\beta_{1}^{\prime} F D I_{i c}+Z_{j i c}^{\prime} \Gamma+\varepsilon_{j i c},
\end{aligned}\right.
$$

where $T A X_{i c}$ is the average tax rate in city $i$ and industry $c$ and ${\overline{Z^{\prime}}}_{i c}$ is a matrix of firm characteristics, averaged for each city-industry cell.

While aggregation bias and endogeneity tend to overstate the effects of FDI on domestic firms' productivity, there is potentially a negative selection bias when limiting the sample to domestic firms, as we discussed above. Since the majority of FDI into China takes the form of mergers and acquisition, the sample of domestic firms is not likely to be randomly formed 22 Rather, the domestic firms may be those that foreign investors found less attractive, because most likely foreign investors will choose to invest in more productive firms. As a result, if for some reason unrelated to productivity a given city-industry cell is more attractive to foreign investors, a larger upper tail of the productivity distribution will be foreign-invested, lowering the mean productivity of remaining domestic firms. Since in the regression analysis we limit ourselves to the sample of domestic firms, we thus might be underestimating the effects of FDI presence ${ }^{23}$ We test whether the selection bias is present in our sample by estimating the effects of FDI on productivity using maximum likelihood Heckman selection model (Heckman, 1979), where in the selection equation we use as instruments

\footnotetext{
${ }^{21}$ Since for service industry the berth capacity and transportation costs are not relevant, we use only average tax rate as an instrument when estimating regressions limited to service sector part of our sample.

${ }^{22}$ In fact, sole foreign ownership was not allowed till the passage in 1986 of the Law of the Peoples Republic of China on Enterprises Operated Exclusively with Foreign Capital.

${ }^{23}$ Note that this problem only arises when measuring horizontal spillovers and is not applicable to our analysis of FDI spillovers through backward and forward linkages.
} 
the same variables as in our IV analysis.

Specifically, we estimated the following system by maximum likelihood:

$$
\left\{\begin{array}{cl}
\operatorname{Prob}\left(D O M_{j i c}\right) & =\lambda_{i}+\lambda_{c}+\lambda_{1} T A X_{i c}+\lambda_{2} \text { Port } * \text { export }_{i c}+\lambda_{3}{\text { Dist } * \text { trcost }_{i c}+Z_{j i c}^{\prime} \Psi+\nu_{i c}}_{Y_{j i c}}=\alpha_{i}+\alpha_{c}+\beta_{1}^{\prime \prime} F D I_{i c}+Z_{j i c}^{\prime} \Gamma+\varepsilon_{j i c}, \quad \text { if } D O M_{j i c}=1
\end{array}\right.
$$

where $D O M_{j i c}$ is an indicator for whether firm $j$ is classified as domestic.

\subsection{Productivity of domestic and foreign firms}

As can be seen from Table 3 foreign firms have a higher labor productivity than domestic firms, SOEs or private. These differences are statistically significant at the $10 \%$ confidence level.

To test whether foreign-invested firms also have higher TFP, we estimate the following regression using a sample of all firms (including both domestic and foreign firms):

$$
y_{j i c}=\beta_{0}+\beta_{1} l_{j i c}+\beta_{2} k_{j i c}+\varepsilon_{j i c}
$$

where $y_{j i c}$ is the $(\log )$ value added of firm $j$ in industry $i$ and city $c, l_{j i c}$ is the labor input and $k_{j i c}$ the capital input of the firm (both in logs), while $\varepsilon_{j i c}$ is a random error term. We then construct the measure of TFP for each firm as the residual from this regression.

The regression is conducted separately for each industry, using year 2000 information. We refer to the residual of the regression in Equation (4) as TFP1. By including additional firm characteristics into the above equation, we compute two alternative measures of TFP. We will refer to the TFP measure net of firm age and firm economy of scale as TFP2 (obtained by adding firm age and firm scale to the explanatory variables), and that net of firm age and firm scale as well as the human capital component, as TFP3 (obtained by adding firm age, firm scale, average education, average age and average age squared to the explanatory variables.)

We then conduct t-tests comparing the TFP of domestic firms with that of firms with positive share of foreign ownership in year 2000. Table 8 gives the t-test results from using the three measures of TFP. All three measures of TFP confirm that foreign firms have significantly higher productivity than domestic firms. The reduction in the TFP gap between foreign and domestic firms from TFP1 to TFP2 and then to TFP3 is explained by the advantages of foreign firms over domestic firms that boost productivity and are controlled for in TFP2 and TFP3: Foreign firms are younger and enjoy greater economy of scale, and they hire younger 
managers and engineers with more education (see Table 3). In fact, differences in firm age and firm scale between foreign and domestic firms are statistically significant, as well as differences in age and education for the high-skilled employees (managers and engineers).

Even after controlling for firm vintage, scale, and average employee education and age, foreign firms still exhibit a significant productivity edge over domestic firms. This difference in productivity is consistent with the argument that FDI embodies more advanced technology and management practices. In turn, the affinity to such advantages brings about positive effects on the productivity of domestics firms located close to the foreign firms (geographically or technologically) ${ }^{24}$ Since the assumption of superior productivity of foreign firms seems justified for our sample ${ }^{25}$ we now turn to testing the hypothesis that these productivity advantages spill over to domestic firms.

\section{FDI spillovers on TFP and labor productivity}

As mentioned previously, we estimate variations of Equation (3) using the sample that includes only domestic firms. Our measure of FDI presence is the average foreign share in each city-industry cell, weighted by firm employment. When we analyze the spillover effects of upstream and downstream FDI presence, the FDI measure is computed using the Input-Output table, as described above.

Table 9 reports estimates of FDI effects on domestic firms' TFP (coefficient $\beta_{1}$ in regression (1)) with the performance measure is the log of value added for each firm. Since the value added is the difference between sales and material costs, it measures firms' value added in terms of revenues, not physical output. Therefore, the measure includes the effects of both quantity produced and sale prices. As Klenow and Hsieh (2006) point out, in a monopolistically competitive environment the two effects are likely to cancel out. In order to avoid this problem, we control for the degree of competition each firm is facing. In addition, FDI presence might be affecting our measure of value added not through productivity spillovers but through the effects on prices and costs (Moran, 2007), which tend to work in the same direction as positive productivity spillovers ${ }^{26}$ We attempt various specifications, where Row (1) includes labor and capital inputs (both in logs) as well as firm age, firm scale, and the degree of competition as explanatory variables, Row (2) adds information on

\footnotetext{
${ }^{24}$ Although a conventional belief, the premise of FDI embodying technological or managerial advantages is challenged by Huang (2003), who provides examples where the "foreign" investor is in fact a domestic firm that first registered in Hong Kong and then returned to the mainland using the foreign entity with the purpose to enjoy the preferential treatment offered to foreigners. We address this problem by using a measure of non-GCA FDI presence.

${ }^{25}$ Note that these results do not necessarily imply that foreign capital increases firm productivity. Due to the "cherrypicking" nature of FDI, establishing such causal relationship, which is not a goal of this paper, would require panel data and more sophisticated analysis. See Arnold and Javorcik (2005) for such a study in the case of Indonesia.

${ }^{26}$ Thus, if we find positive spillovers, we would not be able to distinguish these effects. The same is also true for the measure of labor productivity discussed below.
} 
CEO education and regulatory environment, Row (3) adds information on age and education of technical and managerial personnel to account for labor market effects discussed in Hale and Long (2006) and Moran (2007), while Row (4) adds information on private ownership share. Rows (5)-(8) use different sub-samples to estimate the basic specification used in Row (1): we separate private firms from SOEs because they might respond differently to the presence of FDI; we separate manufacturing firms from service firms mainly because foreign entry to service sector was more restricted before China's accession to WTO in 2001. Row (9) uses the full sample and includes the variables in Row (1) and their interaction terms with industry dummy variables.

Column (1) presents results from OLS estimation, Column (2) computes robust standard errors clustered on city-industry to avoid downward bias in the standard error associated with $\beta_{1}$, Column (3) includes industry and city fixed effects as crude controls for endogeneity of FDI, while Column (4) further computes robust standard errors clustered on city-industry for the FE estimates in Column (3).

Our preferred approach to address the issue of endogeneity is instrumental variable estimation. Columns (5) and (6) present results from using two-stage least squares method (2SLS) and the generalized method of moments (GMM). Compared with 2SLS, GMM produces more efficient estimates (Hayashi, 2000). As described previously, the instruments for FDI include average tax rate, Port *export, and Dist $*$ trcost. The first-stage results are largely consistent with our expectations, with average tax rate having a negative and significant effect on FDI and Port $*$ export having a positive and significant effect.

Finally, column (7) uses Heckman maximum likelihood (ML) estimation to control for the potential selection bias that arises if foreign investors invest in more productive firms, leading to upper truncation of the distribution of domestic firms' productivity. We use the same set of instruments in the selection equation as we do in the IV regressions.

The top panel of Table 9 measures the spillover effects of FDI presence in the same city-industry, the middle panel measures the spillover effects of FDI presence in upstream industries, while the bottom panel measures the spillover effects of FDI presence in downstream industries. Overall, Table 9 presents the results of estimation of 164 regressions.

Some of the results are consistent with the literature. For instance, when we control for human capital and estimate $\beta_{1}$ using simple OLS, we find positive and significant effect of same city-industry FDI presence (top panel, Row (3), Column (1)). However, this effect is no longer significant if we cluster standard errors on city-industry (Column (2)). Adding city and industry fixed effects lowers the coefficient and makes it insignificant with or without clustered standard errors (Columns (3) and (4)), suggesting the upward bias in OLS estimate. While IV regressions lead to higher estimated coefficients in the top panel, these coefficients 
are not statistically significant (Columns (5) and (6)). In fact, none of the IV estimates in Table 9 are significantly different from zero and many of them are, in fact, negative.

Using Heckman ML estimation technique to control for the selection bias, we find that the contribution of this bias is basically zero. We only conduct this analysis for the effects of FDI presence in the same industry as the bias does not arise when measuring the effects of FDI presence in upstream or downstream industries. Comparing Columns (7) and (4), since our Heckman estimation includes industry and city fixed effects, we do not find any effect of the selection bias - in fact, the coefficients are very close to the FE estimation and are not higher than the FE coefficients, as correcting selection bias would imply ${ }^{27}$

We also use labor productivity instead of TFP as a measure of firm performance and obtain very similar results, as shown in Table 10. The only significant estimate from the IV regressions is in the top panel, Row 9, Column 6.

We conduct further robustness tests that we describe here, but do not present as tables, in the interest of space ${ }^{28}$ First of all, we conduct our analysis with an alternative measure of FDI presence, which instead of the share of a largest foreign partner for each firm uses the total share of foreign ownership. This measure is contaminated by portfolio foreign investment. However, since portfolio investment into China is still rather limited, our results differ little from the ones that use our benchmark measure. On notable difference is when our control variable is the log of the total FDI share, we find positive and significant spillovers through backward linkages in our fixed effects specification. However, once we control for the endogeneity of FDI, these effects go away - the coefficients become negative ${ }^{29}$

Then, we estimate the same set of regressions with each of our four alternative measures of FDI presence described above: FDI-majority, FDI-non GCA, FDI-domestic sales, and FDI-non EPZ. The results of these regressions are not reported in the interest of space, but are available from the authors upon requests. Our findings are essentially the same as in Tables 9 and 10, with two exceptions. First, when FDI-majority measures are used, we find positive horizontal spillovers on the service sector TFP and labor productivity, although the coefficients are not statistically significant in any of the IV regressions. When FDI-non GCA measures are used, however, these coefficients become negative. Second, when FDI-domestic sales measures are used, we find positive and significant horizontal spillover effects on TFP and labor productivity in OLS and FE regressions. However, only 4 out of 18 coefficients are significant when we include fixed effects and

\footnotetext{
${ }^{27}$ The only exception is the coefficient in Row 8 which is higher in Column 7 than it is in Column 4, but the difference is statistically insignificant and small.

${ }^{28}$ All of the results are available from authors upon request.

${ }^{29}$ One exception is the effect of upstream FDI in service industry. In this case, which corresponds to the line 8 in the middle panel, we find positive and marginally significant effect in the IV specifications. However, we do not put much faith in this result, because our instruments are not as strong for the service sector firm. In fact, this positive effect is not robust - it disappears when we use the level of FDI measure rather than its log.
} 
cluster standard errors on city-industry. Moreover, vertical spillover effects are negative and significant in this specification. As before, none of the coefficients are significant when IV approach is adopted.

Next, we estimated all of the above regressions using logs of the FDI presence measures instead of levels. Our results remain basically the same, except more coefficients are now positive and significant in OLS specification. However, the significance goes away and the coefficients become smaller when fixed effects are included and standard errors are clustered. Again, none of the coefficients are significant when we control for endogeneity of FDI presence using IV approach.

An additional dimension of FDI spillover effects on Chinese domestic firms studied in the literature is the impact of domestic firms' ownership structure 30 Taking into account of the ownership type, however, does not change the main results obtained for our sample. As shown in Rows (4)-(6) in Table 9 and Table 10 , we find no significant differences in how FDI presence affects the TFP or labor productivity of domestic firms of different ownership types. In contrast, the ownership structure of domestic firms does affect how FDI presence impacts their innovative behaviors, which is the focus of our discussion in the next section.

In summary, we do not find evidence of positive or negative FDI spillover effects on domestic firms' TFP or labor productivity. We also find that some of the positive results obtained in previous studies hold in our sample when the empirical model is misspecified. Once we control for endogeneity, however, we fail to find the evidence of FDI spillovers on domestic firms' productivity.

\section{Conclusion}

In this paper we surveyed the existing literature on the productivity spillovers of FDI presence in China and conducted our own analysis of these effects. Our discussion suggests that many of the empirical estimates of productivity spillover from FDI to domestic firms in China are biased upward. When controlling for these biases, using a large number of specifications to analyze firm-level data, we are unable to find the evidence of spillovers in properly specified regressions. While we are aware of the data-related limitations of our analysis, our results lead us to believe that one is unlikely to find evidence of productivity spillovers from FDI even with a richer data set.

We believe that there are institutional factors that may explain the lack of productivity spillovers of FDI in China. For instance, one important channel of spillovers is technology transfer through labor mobility. In China, however, labor mobility across regions and industries is still limited due to formal labor market restrictions as well as informal barriers. In addition, because of still limited competitive pressure on businesses

\footnotetext{
${ }^{30}$ See, for instance, Buckley, Clegg, and Wang (2002), Hu and Jefferson (2002), and Li, Liu, and Parker (2001).
} 
in many industries, the incentives to adopt superior technology for domestic firms may be weak, lowering potential productivity spillovers from FDI presence.

Nevertheless, that does not necessarily imply that there are no positive or negative spillovers from FDI presence in other forms. For instance, as Moran (2007) points out, quality of the output by domestic firms might improve when they supply foreign-invested companies in downstream industries due to enhanced competition between such firms. Such quality improvements would not be reflected in conventional measures of productivity. FDI presence may also affect the composition of domestic firm sales. In particular, we would expect domestic firms' exports to increase the higher is the presence of FDI due to demonstration effects, networking, training, and quality improvements.

FDI presence may also improve the infrastructure, quality of labor force and R\&D activities of domestic firms, which would have long-term positive effects, but would not show up in productivity measures. In a specific case of China and in transition economies in general, the regulatory environment might improve in response to the FDI presence. We are leaving the exploration of these issues to future research. 


\section{References}

Aitken, B., and A. Harrison (1999): "Do Domestic Firms Benefit from Direct Foreign Investment? Evidence from Venezuela," American Economic Review, 90(3), 605-618.

Arnold, J., And B. S. Javorcik (2005): "Gifted Kids or Pushy Parents? Foreign Acquisitions and Plant Performance in Indonesia," CEPR Discussion Papers: 5065.

Bagchi-Sen, S., and J. Wheeler (1989): "A spatial and temporal model of foreign direct investment in the United States," Economic Geography, 65(2), 113-129, population size, population growth, and per capita retail sales.

Blalock, G., and P. Gertler (2007): "Welfare Gains from Foreign Direct Investment through Technology Transfer to Local Suppliers," Journal of International economics, forthcoming.

Blomstrom, M., and R. LiPSEy (1991): "Firm size and foreign operations of multinationals," Scandinavian Journal of Economics, 93(1), 101-107, domestic market size.

Blonigen, B. A. (2005): "A Review of the Empirical Literature on FDI Determinants," NBER Working Paper, 11299.

Buckley, P. J., J. ClegG, and C. WANG (2002): "The impact of inward FDI on the performance of Chinese manufacturing firms," Journal of International Business Studies, 33(4), 637-655.

Cheng, L. K., And Y. K. Kwanb (2000): "What are the determinants of the location of foreign direct investment? The Chinese experience," Journal of International Economics, 51, 379-400.

Cheung, K.-Y., And P. Lin (2004): "Spillover effects of FDI on innovation in China: Evidence from the provincial data," China Economic Review, 15(1), 25-44.

Chuang, Y.-C., and P.-F. Hsu (2004): "FDI, trade, and spillover efficiency: evidence from China's manufacturing sector," Applied Economics, 36, 1103-1115.

Coughlin, C., J. Terza, and V. Arromdee (1991): "State characteristics and the location of foreign direct investment within the United States," Review of Economics and Statistics, 73(4), 675683, tax rate and infrastructure.

De Mooij, R. A., And S. Ederveen (2003): "Taxation and Foreign Direct Investment: A Synthesis of Empirical Research," International Tax and Public Finance, 10(6), 673-693, tax rate.

Fosfuri, A., M. Motta, and T. Rønde (2001): "Foreign Direct Investment and Spillovers through Workers Mobility," Journal of International Economics, 53(1), 205-222.

Glass, A., And K. SagGi (2002): "Multinational Firms and Technology Transfer," Scandinavian Journal of Economics, 104(4), 495-514.

Görg, H., and D. Greenaway (2004): "Much Ado about Nothing? Do Domestic Firms Really Benefit from Foreign Direct Investment?," World Bank Research Observer, 19(2), 171-197.

HAAKeR, M. (1999): "Spillovers from Foreign Direct Investment through Labour Turnover: The Supply of Management Skills," Discussion Paper, London Scool of Economics.

Hale, G., and C. Long (2006): "FDI Spillovers and Firm Ownership in China: Labor Markets and Backward Linkages," Pacific Basin Working Paper.

Hallward-Driemeier, M., S. J. Wallsten, and L. C. Xu (2003): "The Investment Climate and the Firm: Firm-Level Evidence from China," World Bank Policy Research Working Paper No. 3003.

Hayashi, F. (2000): Econometrics. Princeton University Press, efficiency of GMM compared to 2SLS.

Heckman, J. (1979): "Sample Selection Bias as a Specification Error," Econometrica, 47, 153-161. 
Hu, A. G., And G. H. JefFerson (2002): "FDI Impact and Spillover: Evidence from China's Electronic and Textile Industries," The World Economy, 25, 1063-1076.

Huang, J.-T. (2004): "Spillovers from Taiwan, Hong Kong, and Macau investment and from other foreign investment in Chinese industries," Contemporary economic policy, 22(1), 13-25.

Huang, Y. (2003): Selling China: Foreign direct investment during the reform era, Cambridge Modern China Series. Cambridge; New York and Melbourne: Cambridge University Press.

Javorcik, B. S. (2004): "Does Foreign Direct Investment Increase the Productivity of Domestic Firms? In Search of Spillovers through Backward Linkages," American Economic Review, 93(3), 605-627.

Kaufmann, L. (1997): "A Model of Spillovers trough Labor Recruitment," International Economic Journal, 11(3), 13-34.

Klenow, P., And C.-T. Hsieh (2006): "Misallocation and Manufacturing TFP in China and India," photocopy.

Kravis, I., AND R. LIPSEY (1982): "The location of overseas production and production for export by U.S. multinational firms," Journal of International Economics, 12(3/4), 201-223, domestic market size.

Li, X., X. Liu, and D. Parker (2001): "Foreign direct investment and productivity spillovers in the Chinese manufacturing sector," Economic Systems, 25(4), 305-321.

Liu, X., D. Parker, K. Vaidya, and Y. Wei (2001): "The impact of foreign direct investment on labour productivity in the Chinese electronics industry," International Business Review, 10(4), 421-439.

LiU, Z. (2001): "Foreign direct investment and technology spillover: evidence from China," Journal of Comparative Economics, 30(3), 579-602.

MA, A. C. (2006): "Geographical Location of Foreign Direct Investment and Wage Inequality in China," The World Economy, 29(8), 1031-1055, access to international market.

Moran, T. H. (2007): "How to Investigate the Impact of Foreign Direct Investment on Development, and Use the Results to Guide Policy," Paper prepared for the Brookings conference.

Moulton, B. R. (1990): "An Illustration of a Pitfall in Estimating the Effects of Aggregate Variables on Micro Units," The Review of Economics and Statistics, 72(2), 334-338.

Razin, A., Y. Rubinshtein, and E. SAdKA (2005): "Corporate Taxation and Bilateral FDI with Threshold Barriers," mimeo, Cornell University.

Rodriguez-Clare, A. (1996): "Multinationals, Linkages, and Economic Development," American Economic Review, 86(4), 852-873.

Sun, Q., W. Tong, AND Q. Yu (2002): "Determinants of foreign direct investment across China," Journal of International Money and Finance, 21, 79-113.

Tong, S. Y., And A. Y. Hu (2003): "Do Domestic Firms Benefit from Foreign Direct Investment? Initial Evidence from Chinese Manufacturing," mimeo, The University of Hong Kong.

Wang, J.-Y., and M. Blomstrom (1992): "Foreign Investment and Technology Transfer: A Simple Model," European Economic Review, 36(1), 137-155.

WeI, Y., And X. LIU (2006): "Productivity spillovers from R\&D, exports and FDI in China's manufacturing sector," Journal of International Business Studies, 37(4), 544-557.

XU, B., And J. Lu (2006): "The Impact of Foreign Firms on the Sophistication of Chinese Exports," China Europe International Business School Working Paper. 


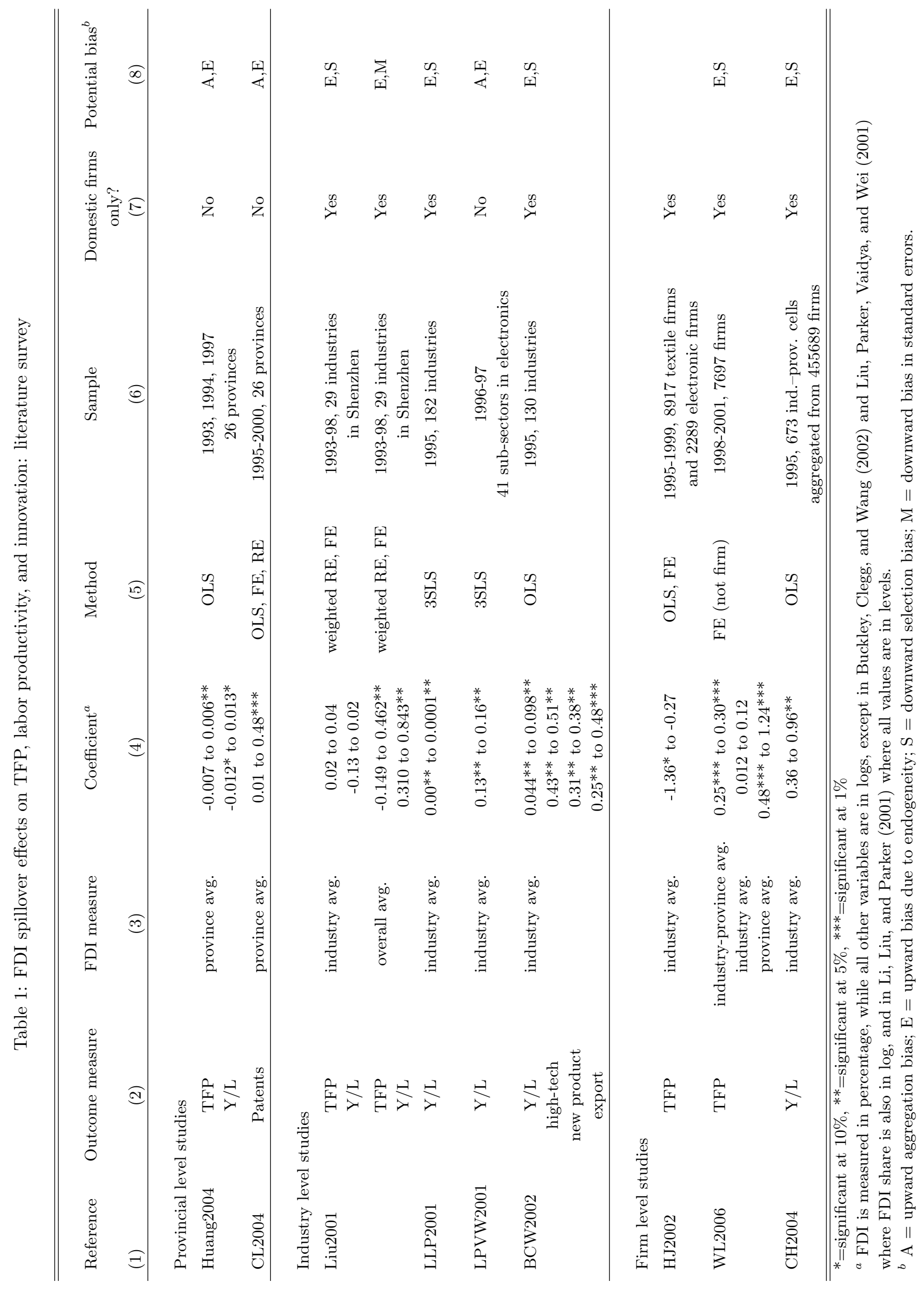


Table 2: Distribution of Foreign and Domestic Firms

\begin{tabular}{lcccc}
\hline \hline & All & Foreign & Domestic & Share of foreign \\
\hline $\begin{array}{l}\text { Number of firms } \\
\text { by city: }\end{array}$ & 1500 & 382 & 1118 & 0.25 \\
1. Beijing & 300 & 75 & 225 & 0.25 \\
2. Chengdu & 300 & 32 & 268 & 0.11 \\
3. Guangzhou & 300 & 84 & 216 & 0.28 \\
4. Shanghai & 300 & 122 & 178 & 0.41 \\
5. Tianjin & 300 & 69 & 231 & 0.23 \\
by industry: & & & & \\
manufacturing: & & & & \\
1. Apparel and leather & 222 & 63 & 159 & 0.28 \\
2. Consumer products & 165 & 40 & 125 & 0.24 \\
3. Electronic components & 203 & 77 & 126 & 0.38 \\
4. Electronic equipment & 192 & 65 & 127 & 0.34 \\
5. Vehicles and parts & 216 & 65 & 151 & 0.30 \\
services: & & & & \\
6. Accounting etc. & 104 & 11 & 93 & 0.11 \\
7. Advertising and marketing & 89 & 15 & 74 & 0.17 \\
8. Business logistics services & 110 & 22 & 88 & 0.2 \\
9. Communication services & 71 & 3 & 68 & 0.04 \\
10. IT services & 128 & 21 & 107 & 0.16 \\
\hline \hline
\end{tabular}

Table 3: Summary statistics of the firm variables

\begin{tabular}{|c|c|c|c|c|c|c|c|c|c|}
\hline \multirow[b]{2}{*}{ Variable } & \multicolumn{3}{|c|}{ Foreign } & \multicolumn{3}{|c|}{ Domestic-SOE } & \multicolumn{3}{|c|}{ Domestic-Private } \\
\hline & N.obs. & Mean & S.D. & N.obs. & Mean & S.D. & N.obs. & Mean & S.D. \\
\hline $\log$ (value added) & 311 & 10.0 & 1.92 & 511 & 8.86 & 2.05 & 223 & 8.72 & 1.93 \\
\hline $\log (\mathrm{Y} / \mathrm{L})$ & 311 & 4.43 & 1.36 & 511 & 3.32 & 1.39 & 223 & 3.65 & 1.20 \\
\hline $\log ($ capital) & 382 & 10.0 & 2.18 & 773 & 8.92 & 2.58 & 333 & 7.95 & 2.32 \\
\hline Log(labor) & 382 & 5.41 & 1.46 & 779 & 5.17 & 1.60 & 339 & 4.63 & 1.44 \\
\hline Capital/Labor & 382 & 4.60 & 1.41 & 773 & 3.74 & 1.56 & 333 & 3.30 & 1.44 \\
\hline Firm age & 382 & 8.29 & 8.79 & 779 & 17.2 & 18.1 & 338 & 6.45 & 7.33 \\
\hline Firm scale & 381 & 2.36 & 11.4 & 775 & 0.60 & 3.44 & 335 & 0.38 & 1.34 \\
\hline Degree of competition & 352 & 0.71 & 4.42 & 718 & 0.96 & 5.38 & 314 & 1.42 & 5.68 \\
\hline Exporter & 382 & 0.59 & 0.49 & 779 & 0.17 & 0.38 & 339 & 0.29 & 0.45 \\
\hline CEO-college & 382 & 0.91 & 0.29 & 779 & 0.83 & 0.37 & 339 & 0.79 & 0.41 \\
\hline CEO-grad. degree & 382 & 0.23 & 0.42 & 779 & 0.15 & 0.36 & 339 & 0.15 & 0.36 \\
\hline Favorable regulations & 382 & 0.20 & 0.40 & 779 & 0.10 & 0.30 & 339 & 0.14 & 0.35 \\
\hline Average education & 320 & 13.3 & 1.36 & 588 & 12.9 & 1.40 & 235 & 13.1 & 1.45 \\
\hline Average age & 320 & 33.8 & 6.11 & 589 & 37.0 & 6.07 & 233 & 32.9 & 6.77 \\
\hline Private share & 382 & 0.59 & 0.30 & 779 & 0.07 & 0.17 & 339 & 0.99 & 0.03 \\
\hline
\end{tabular}


Table 4: Foreign share by city and industry sector

\begin{tabular}{lcccccc}
\hline \hline & & & & & \\
Industry, city & Beijing & Chengdu & Guangzhou & Shanghai & Tianjin & Overall \\
\hline & & & & & & \\
Apparel and leather goods & 0.169 & 0.010 & 0.207 & 0.178 & 0.278 & 0.167 \\
Consumer products & 0.099 & 0.065 & 0.113 & 0.156 & 0.310 & 0.153 \\
Electronic components & 0.165 & 0.029 & 0.219 & 0.306 & 0.473 & 0.239 \\
Electronic equipment & 0.244 & 0.018 & 0.108 & 0.360 & 0.262 & 0.202 \\
Vehicles and vehicle parts & 0.113 & 0.093 & 0.135 & 0.255 & 0.121 & 0.141 \\
& & & & & & 0.052 \\
Accounting and related services & 0.182 & 0.000 & 0.007 & 0.030 & 0.019 & 0.075 \\
Advertising and marketing & 0.037 & 0.010 & 0.014 & 0.098 & 0.193 & 0.031 \\
Business logistics services & 0.006 & 0.000 & 0.062 & 0.041 & 0.041 & 0.004 \\
Communication services & 0.000 & 0.010 & 0.000 & 0.003 & 0.002 & 0.084 \\
Information technology services & 0.076 & 0.047 & 0.029 & 0.332 & 0.006 & 0.138 \\
\hline
\end{tabular}

Table 5: Input-output table for industries in our sample

\begin{tabular}{lcccccccccc}
\hline \hline & & & & & & & & & & \\
Input industry, output industry & $(1)$ & $(2)$ & $(3)$ & $(4)$ & $(5)$ & $(6)$ & $(7)$ & $(8)$ & $(9)$ & $(10)$ \\
(1) Apparel \& leather & 0.783 & 0.062 & 0.062 & 0.062 & 0.062 & 0.036 & 0.019 & 0.056 & 0.056 & 0.056 \\
(2) Consumer products & 0.139 & 0.786 & 0.786 & 0.786 & 0.786 & 0.372 & 0.114 & 0.230 & 0.230 & 0.230 \\
(3) Electronic components & 0.139 & 0.786 & 0.786 & 0.786 & 0.786 & 0.372 & 0.114 & 0.230 & 0.230 & 0.230 \\
(4) Electronic equipment & 0.139 & 0.786 & 0.786 & 0.786 & 0.786 & 0.372 & 0.114 & 0.230 & 0.230 & 0.230 \\
(5) Vehicle \& vehicle parts & 0.139 & 0.786 & 0.786 & 0.786 & 0.786 & 0.372 & 0.114 & 0.230 & 0.230 & 0.230 \\
(6) Business logistics & 0.064 & 0.090 & 0.090 & 0.090 & 0.090 & 0.080 & 0.051 & 0.131 & 0.131 & 0.131 \\
(7) Accounting & 0.037 & 0.051 & 0.051 & 0.051 & 0.051 & 0.038 & 0.062 & 0.041 & 0.041 & 0.041 \\
(8) Advertising \& marketing & 0.011 & 0.012 & 0.012 & 0.012 & 0.012 & 0.014 & 0.008 & 0.036 & 0.036 & 0.036 \\
(9) Information technology services & 0.011 & 0.012 & 0.012 & 0.012 & 0.012 & 0.014 & 0.008 & 0.036 & 0.036 & 0.036 \\
(10) Communications services & 0.011 & 0.012 & 0.012 & 0.012 & 0.012 & 0.014 & 0.008 & 0.036 & 0.036 & 0.036 \\
\hline \hline
\end{tabular}

Source: Adapted from 2000 Input-Output Table for China 
Table 6: Upstream and downstream FDI presence by city and industry

\begin{tabular}{|c|c|c|c|c|c|c|}
\hline \multicolumn{7}{|l|}{ FDI presence upstream } \\
\hline Industry, city & Beijing & Chengdu & Guangzhou & Shanghai & Tianjin & Overall \\
\hline apparel and leather goods & 0.088 & 0.031 & 0.131 & 0.196 & 0.108 & 0.108 \\
\hline consumer products & 0.365 & 0.142 & 0.615 & 0.889 & 0.450 & 0.511 \\
\hline electronic components & 0.323 & 0.144 & 0.448 & 0.761 & 0.365 & 0.406 \\
\hline electronic equipment & 0.283 & 0.126 & 0.540 & 0.753 & 0.400 & 0.428 \\
\hline vehicles and vehicle parts & 0.344 & 0.104 & 0.549 & 0.839 & 0.505 & 0.461 \\
\hline accounting and related services & 0.071 & 0.026 & 0.111 & 0.163 & 0.090 & 0.091 \\
\hline advertising and marketing & 0.157 & 0.052 & 0.233 & 0.338 & 0.193 & 0.192 \\
\hline business logistics services & 0.200 & 0.082 & 0.332 & 0.509 & 0.263 & 0.280 \\
\hline communication services & 0.163 & 0.052 & 0.236 & 0.342 & 0.195 & 0.204 \\
\hline information technology services & 0.158 & 0.051 & 0.233 & 0.332 & 0.195 & 0.191 \\
\hline Overall & 0.226 & 0.088 & 0.375 & 0.571 & 0.304 & 0.313 \\
\hline \multicolumn{7}{|l|}{ FDI presence downstream } \\
\hline Industry, city & Beijing & Chengdu & Guangzhou & Shanghai & Tianjin & Overall \\
\hline apparel and leather goods & 0.056 & 0.017 & 0.067 & 0.109 & 0.056 & 0.060 \\
\hline consumer products & 0.503 & 0.155 & 0.706 & 1.013 & 0.545 & 0.600 \\
\hline electronic components & 0.460 & 0.157 & 0.539 & 0.885 & 0.460 & 0.499 \\
\hline electronic equipment & 0.421 & 0.139 & 0.632 & 0.877 & 0.496 & 0.523 \\
\hline vehicles and vehicle parts & 0.481 & 0.118 & 0.640 & 0.963 & 0.600 & 0.553 \\
\hline accounting and related services & 0.051 & 0.014 & 0.065 & 0.094 & 0.054 & 0.055 \\
\hline advertising and marketing & 0.017 & 0.005 & 0.018 & 0.030 & 0.015 & 0.017 \\
\hline business logistics services & 0.105 & 0.028 & 0.116 & 0.185 & 0.096 & 0.107 \\
\hline communication services & 0.023 & 0.004 & 0.021 & 0.034 & 0.017 & 0.020 \\
\hline information technology services & 0.018 & 0.003 & 0.018 & 0.024 & 0.018 & 0.016 \\
\hline Overall & 0.254 & 0.079 & 0.350 & 0.537 & 0.299 & 0.304 \\
\hline
\end{tabular}


Table 7: Summary of cell-level instrumental variables

\begin{tabular}{|c|c|c|c|c|c|c|}
\hline \multicolumn{7}{|l|}{ Average tax rate } \\
\hline Industry, city & Beijing & Chengdu & Guangzhou & Shanghai & Tianjin & Overall \\
\hline apparel and leather goods & 0.29 & 1.21 & 0.63 & 0.15 & 0.48 & 0.56 \\
\hline consumer products & 0.21 & 0.74 & 0.07 & 0.06 & 0.26 & 0.27 \\
\hline electronic components & 0.12 & 0.60 & 0.74 & 0.35 & 0.75 & 0.51 \\
\hline electronic equipment & 0.28 & 1.46 & 0.39 & 0.03 & 0.15 & 0.44 \\
\hline vehicles and vehicle parts & 0.19 & 0.48 & 0.21 & 0.20 & 0.61 & 0.35 \\
\hline accounting and related services & 1.42 & 7.64 & 0.70 & 0.71 & 7.40 & 3.68 \\
\hline advertising and marketing & 0.46 & 3.75 & 0.95 & 0.88 & 0.47 & 1.32 \\
\hline business logistics services & 0.69 & 3.96 & 0.25 & 0.38 & 2.50 & 1.41 \\
\hline communication services & 0.04 & 3.41 & 0.03 & 0.27 & 0.03 & 0.91 \\
\hline information technology services & 0.68 & 2.18 & 0.48 & 0.18 & 1.63 & 1.05 \\
\hline Overall & 0.40 & 1.97 & 0.43 & 0.27 & 1.22 & 0.86 \\
\hline \multicolumn{7}{|l|}{ Port*export } \\
\hline Industry, city & Beijing & Chengdu & Guangzhou & Shanghai & Tianjin & Overall \\
\hline apparel and leather goods & 0.00 & 0.00 & 74.13 & 127.54 & 39.24 & 45.76 \\
\hline consumer products & 0.00 & 0.00 & 42.86 & 73.75 & 22.69 & 31.26 \\
\hline electronic components & 0.00 & 0.00 & 78.38 & 134.87 & 41.50 & 50.02 \\
\hline electronic equipment & 0.00 & 0.00 & 50.29 & 86.53 & 26.63 & 33.50 \\
\hline vehicles and vehicle parts & 0.00 & 0.00 & 49.11 & 84.50 & 26.00 & 30.73 \\
\hline accounting and related services & 0.00 & 0.00 & 1.31 & 2.25 & 0.69 & 0.81 \\
\hline advertising and marketing & 0.00 & 0.00 & 1.53 & 2.63 & 0.81 & 0.95 \\
\hline business logistics services & 0.00 & 0.00 & 8.65 & 14.89 & 4.58 & 5.74 \\
\hline communication services & 0.00 & 0.00 & 0.00 & 0.00 & 0.00 & 0.00 \\
\hline information technology services & 0.00 & 0.00 & 9.56 & 16.45 & 5.06 & 5.96 \\
\hline Overall & 0.00 & 0.00 & 41.78 & 70.04 & 21.86 & 26.74 \\
\hline \multicolumn{7}{|l|}{ Dist*tr.cost } \\
\hline Industry, city & Beijing & Chengdu & Guangzhou & Shanghai & Tianjin & Overall \\
\hline apparel and leather goods & 0.116 & 0.026 & 0.021 & 0.100 & 0.121 & 0.076 \\
\hline consumer products & 0.048 & 0.011 & 0.009 & 0.042 & 0.051 & 0.031 \\
\hline electronic components & 0.104 & 0.023 & 0.019 & 0.090 & 0.108 & 0.070 \\
\hline electronic equipment & 0.050 & 0.011 & 0.009 & 0.043 & 0.052 & 0.033 \\
\hline vehicles and vehicle parts & 0.082 & 0.018 & 0.015 & 0.071 & 0.085 & 0.055 \\
\hline accounting and related services & 0.004 & 0.001 & 0.001 & 0.004 & 0.004 & 0.003 \\
\hline advertising and marketing & 0.050 & 0.011 & 0.009 & 0.043 & 0.052 & 0.035 \\
\hline business logistics services & 0.272 & 0.060 & 0.050 & 0.236 & 0.284 & 0.170 \\
\hline communication services & 0.079 & 0.018 & 0.014 & 0.069 & 0.083 & 0.051 \\
\hline information technology services & 0.055 & 0.012 & 0.010 & 0.048 & 0.058 & 0.036 \\
\hline Overall & 0.088 & 0.019 & 0.017 & 0.073 & 0.086 & 0.057 \\
\hline
\end{tabular}


Table 8: Comparison of Foreign and Domestic Firms' TFP

\begin{tabular}{lccc}
\hline \hline & & & \\
& Foreign & Domestic & Difference \\
\hline \multirow{2}{*}{ TFP1 } & & & \\
& 0.32 & -0.22 & $0.54^{* * *}$ \\
TFP2 & $(311)$ & $(730)$ & $(7.32)$ \\
& 0.14 & -0.16 & $0.30^{* * *}$ \\
TFP3 & $(311)$ & $(722)$ & $(4.48)$ \\
& 0.10 & -0.13 & $0.23^{* *}$ \\
& $(189)$ & $(423)$ & $(2.52)$ \\
\hline \hline
\end{tabular}

$*$ significant at $10 \% ;{ }^{* *}$ significant at $5 \% ; * * *$ significant at $1 \%$ 
Table 9: FDI spillover effects on TFP in our sample

\begin{tabular}{|c|c|c|c|c|c|c|c|c|}
\hline Controls & Sample & $\begin{array}{l}\text { OLS } \\
(1)\end{array}$ & $\begin{array}{c}\text { OLS + cluster } \\
(2)\end{array}$ & $\begin{array}{l}\mathrm{FE} \\
(3)\end{array}$ & $\begin{array}{c}\text { FE+cluster } \\
(4)\end{array}$ & $\begin{array}{c}\mathrm{IV}-2 \mathrm{SLS}^{a} \\
(5)\end{array}$ & $\begin{array}{c}\mathrm{IV}^{-G_{M M M}}{ }^{a} \\
(6)\end{array}$ & $\begin{array}{c}\operatorname{Heckman}^{a} \\
(7)\end{array}$ \\
\hline \multicolumn{9}{|c|}{$\beta$ coefficient on FDI presence } \\
\hline 1. TFP controls & Full & 0.10 & 0.10 & -0.16 & -0.16 & 2.03 & 2.27 & -0.18 \\
\hline 2. TFP controls, $\mathrm{X}$ & Full & 0.20 & 0.20 & 0.06 & 0.06 & 1.97 & 1.94 & 0.04 \\
\hline 3. TFP controls, E & Full & $1.01^{* *}$ & 1.01 & 0.36 & 0.36 & 1.76 & 1.80 & 0.36 \\
\hline 4. TFP controls, PR & Full & 0.14 & 0.14 & -0.19 & -0.19 & 1.88 & 2.12 & -0.21 \\
\hline 5. TFP controls & Private & 0.24 & 0.24 & 1.70 & 1.70 & -0.35 & $-0.20^{b}$ & 1.68 \\
\hline 6. TFP controls & SOE & 0.03 & 0.03 & -0.82 & -0.82 & 4.17 & 4.16 & N.A. \\
\hline 7. TFP controls & Manuf. & -0.10 & -0.10 & -0.42 & -0.42 & 1.90 & 1.70 & -0.44 \\
\hline 8. TFP controls & Service & $3.35^{*}$ & 3.35 & 2.35 & 2.35 & -22.92 & -22.92 & 2.79 \\
\hline 9. Interacted TFP & Full & N.A. & N.A. & -0.38 & -0.38 & -4.28 & $-4.17^{c}$ & -0.43 \\
\hline \multicolumn{9}{|c|}{$\beta$ coefficient on upstream FDI presence } \\
\hline 1. TFP controls & Full & 0.05 & 0.05 & -0.20 & -0.20 & 0.40 & 0.66 & \\
\hline 2. TFP controls, $\mathrm{X}$ & Full & 0.06 & 0.06 & -0.41 & -0.41 & -0.22 & -0.04 & \\
\hline 3. TFP controls, E & Full & $0.43^{* *}$ & 0.43 & -0.06 & -0.06 & -0.39 & -0.13 & \\
\hline 4. TFP controls, PR & Full & 0.08 & 0.08 & -0.30 & -0.30 & 0.39 & 0.62 & \\
\hline 5. TFP controls & Private & 0.04 & 0.04 & -0.23 & -0.23 & -1.15 & $0.17^{b}$ & \\
\hline 6. TFP controls & SOE & 0.03 & 0.03 & -0.28 & -0.28 & 0.37 & 0.73 & \\
\hline 7. TFP controls & Manuf. & 0.02 & 0.02 & -0.39 & -0.39 & -0.84 & -0.71 & \\
\hline 8. TFP controls & Service & -0.53 & -0.53 & 0.39 & 0.39 & -4.97 & -5.35 & \\
\hline 9. Interacted TFP & Full & N.A. & N.A. & 0.04 & 0.04 & 0.45 & $0.25^{c}$ & \\
\hline \multicolumn{9}{|c|}{$\beta$ coefficient on downstream FDI presence } \\
\hline 1. TFP controls & Full & 0.04 & 0.04 & -0.13 & -0.13 & 0.56 & 0.66 & \\
\hline 2. TFP controls, $\mathrm{X}$ & Full & 0.06 & 0.06 & -0.28 & -0.28 & 0.13 & 0.21 & \\
\hline 3. TFP controls, E & Full & $0.38^{* *}$ & 0.38 & -0.01 & -0.01 & -0.28 & -0.09 & \\
\hline 4. TFP controls, PR & Full & 0.06 & 0.06 & -0.20 & -0.20 & 0.53 & 0.62 & \\
\hline 5. TFP controls & Private & 0.00 & 0.00 & 0.07 & 0.07 & -1.20 & $0.18^{b}$ & \\
\hline 6. TFP controls & SOE & 0.03 & 0.03 & -0.23 & -0.23 & 0.73 & 0.82 & \\
\hline 7. TFP controls & Manuf. & 0.05 & 0.05 & -0.41 & -0.41 & -0.65 & -0.56 & \\
\hline 8. TFP controls & Service & -4.92 & -4.92 & 1.47 & 1.47 & -0.23 & 117.77 & \\
\hline 9. Interacted TFP & Full & N.A. & N.A. & -0.08 & -0.08 & -0.13 & $-0.21^{c}$ & \\
\hline
\end{tabular}

Dependent variable in all regressions is $\log$ (Value added)

TFP controls $=\log ($ Capital $), \log ($ Labor $)$, Firm age, Firm scale, Degree of competition

$\mathrm{X}=\mathrm{I}(\mathrm{CEO}$ has college education), I(CEO has graduate degree), I(Good regulatory environment)

$\mathrm{E}=$ Average education, Average age, Average age ${ }^{2}$ of technical and management personnel

$\mathrm{PR}=$ share of private ownership of the firm

Interacted TFP $=$ each of the TFP variables interacted with 10 industry dummy variables

Instruments: Average tax rate in city-industry cell, port*export share in industry, proximity to major cities*avg. transportation costs in industry

$*$ =significant at $10 \%, * *=$ significant at $5 \%, * * *=$ significant at $1 \%$

${ }^{a}$ include industry and city effects and standard errors clustered on city-industry

${ }^{b}$ No industry or city effects due to insufficient number of observations

${ }^{c}$ Robust standard errors, not clustered on city-industry cell, due to insufficient degrees of freedom 
Table 10: FDI spillover effects on labor productivity in our sample

\begin{tabular}{|c|c|c|c|c|c|c|c|c|}
\hline Controls & Sample & $\begin{array}{l}\text { OLS } \\
(1)\end{array}$ & $\begin{array}{c}\text { OLS+cluster } \\
(2)\end{array}$ & $\begin{array}{l}\mathrm{FE} \\
(3) \\
\end{array}$ & $\begin{array}{c}\mathrm{FE}+\text { cluster } \\
(4)\end{array}$ & $\begin{array}{c}\mathrm{IV}-2 \mathrm{SLS}^{a} \\
(5)\end{array}$ & $\begin{array}{c}\text { IV-GMM } \\
(6)\end{array}$ & $\begin{array}{c}\text { Heckman }^{a} \\
(7)\end{array}$ \\
\hline \multicolumn{9}{|c|}{$\beta$ coefficient on FDI presence } \\
\hline 1. TFP controls & Full & 0.18 & 0.18 & 0.49 & 0.49 & -0.77 & 0.33 & 0.46 \\
\hline 2. TFP controls, $\mathrm{X}$ & Full & 0.41 & 0.41 & 0.88 & 0.88 & -0.54 & 0.08 & 0.85 \\
\hline 3. TFP controls, $\mathrm{E}$ & Full & $1.26 * *$ & 1.26 & 1.18 & 1.18 & -2.32 & -0.53 & 1.17 \\
\hline 4. TFP controls, PR & Full & 0.24 & 0.24 & 0.46 & 0.46 & -0.95 & 0.00 & 0.43 \\
\hline 5. TFP controls & Private & 0.41 & 0.41 & 2.51 & 2.51 & 1.97 & $0.11^{b}$ & 2.52 \\
\hline 6. TFP controls & $\mathrm{SOE}$ & 0.08 & 0.08 & -0.20 & -0.20 & -0.01 & 1.58 & N.A. \\
\hline 7. TFP controls & Manuf. & $-1.26^{* *}$ & -1.26 & 0.28 & 0.28 & -5.57 & -5.88 & 0.28 \\
\hline 8. TFP controls & Service & 3.78 & 3.78 & 3.61 & 3.61 & -26.59 & -26.59 & 4.28 \\
\hline 9. Interacted TFP & Full & N.A. & N.A. & 0.31 & 0.31 & -6.79 & $-6.76^{* c}$ & 0.28 \\
\hline \multicolumn{9}{|c|}{$\beta$ coefficient on upstream FDI presence } \\
\hline 1. TFP controls & Full & -0.14 & -0.14 & 0.75 & 0.75 & 0.93 & 0.66 & \\
\hline 2. TFP controls, $\mathrm{X}$ & Full & -0.07 & -0.07 & 0.28 & 0.28 & -0.37 & -0.66 & \\
\hline 3. TFP controls, E & Full & 0.37 & 0.37 & 1.00 & $1.00^{*}$ & 1.99 & 1.99 & \\
\hline 4. TFP controls, PR & Full & -0.10 & -0.10 & 0.64 & 0.64 & 0.91 & 0.65 & \\
\hline 5. TFP controls & Private & $-0.76^{*}$ & -0.76 & -0.02 & -0.02 & -2.57 & $0.48^{b}$ & \\
\hline 6. TFP controls & SOE & 0.06 & 0.06 & 0.96 & $0.96^{*}$ & 0.27 & 0.29 & \\
\hline 7. TFP controls & Manuf. & $-0.69 * * *$ & $-0.69^{*}$ & 0.57 & 0.57 & 1.07 & 1.17 & \\
\hline 8. TFP controls & Service & 0.43 & 0.43 & $11.58^{*}$ & 11.58 & 6.00 & 4.85 & \\
\hline 9. Interacted TFP & Full & N.A. & N.A. & 0.45 & 0.45 & 0.98 & $0.85^{c}$ & \\
\hline \multicolumn{9}{|c|}{$\beta$ coefficient on downstream FDI presence } \\
\hline 1. TFP controls & Full & 0.10 & 0.10 & 0.47 & 0.47 & 0.68 & 0.58 & \\
\hline 2. TFP controls, $\mathrm{X}$ & Full & 0.15 & 0.15 & 0.15 & 0.15 & -0.22 & -0.38 & \\
\hline 3. TFP controls, E & Full & $0.49^{* *}$ & 0.49 & 0.82 & $0.82^{*}$ & 1.56 & 1.61 & \\
\hline 4. TFP controls, PR & Full & 0.12 & 0.12 & 0.40 & 0.40 & 0.62 & 0.52 & \\
\hline 5. TFP controls & Private & -0.30 & -0.30 & 0.21 & 0.21 & -2.13 & $0.72^{b}$ & \\
\hline 6. TFP controls & $\mathrm{SOE}$ & 0.19 & 0.19 & 0.57 & 0.57 & 0.25 & 0.34 & \\
\hline 7. TFP controls & Manuf. & $-0.49 * *$ & -0.49 & 0.49 & 0.49 & 0.82 & 0.90 & \\
\hline 8. TFP controls & Service & 4.06 & 4.06 & 14.93 & 14.93 & 14.43 & 127.31 & \\
\hline 9. Interacted TFP & Full & N.A. & N.A. & 0.27 & 0.27 & 0.14 & $-0.04^{c}$ & \\
\hline
\end{tabular}

Dependent variable in all regressions is $\log$ (Value added/labor)

$\mathrm{Y} / \mathrm{L}$ controls $=\log ($ Capital/labor $)$, Firm age, Firm scale, Degree of competition

$\mathrm{X}=\mathrm{I}(\mathrm{CEO}$ has college education), I(CEO has graduate degree), I(Good regulatory environment)

$\mathrm{E}=$ Average education, Average age, Average age ${ }^{2}$ of technical and management personnel

$\mathrm{PR}=$ share of private ownership of the firm

Interacted $\mathrm{Y} / \mathrm{L}=$ each of the $\mathrm{Y} / \mathrm{L}$ variables interacted with 10 industry dummy variables

Instruments: Average tax rate in city-industry cell, port*export share in industry, proximity to major cities*avg. transportation costs in industry

$*=$ significant at $10 \%, * *=$ significant at $5 \%, * * *=$ significant at $1 \%$

${ }^{a}$ include industry and city effects and standard errors clustered on city-industry

${ }^{b}$ No industry or city effects due to insufficient number of observations

${ }^{c}$ Robust standard errors, not clustered on country, due to insufficient degrees of freedom

${ }^{d}$ Two-step rather than ML Heckman estimation 